\title{
Enhancement of butyrate production in the rat caecocolonic tract by long-term ingestion of resistant potato starch
}

\author{
Gwenaëlle Le Blay, Catherine Michel, Hervé M. Blottière and Christine Cherbut* \\ Human Nutrition Research Centre, INRA, BP 71627, 44316 Nantes Cedex 03, France
}

(Received 19 October 1998 - Revised 26 April 1999 - Accepted 18 May 1999)

\begin{abstract}
Some data suggest that the colonic microflora may adapt to produce more butyrate if given time and the proper substrate. To test this hypothesis, we investigated the effect of prolonged feeding of resistant potato starch on butyrate production. Rats were fed on either a low-fibre diet (basal) or the same diet supplemented with $90 \mathrm{~g}$ resistant potato starch/kg $(\mathrm{PoS})$ for $0.5,2$ and 6 months. Short-chain fatty acid (SCFA) concentrations were determined in caecal and colonic contents at the end of each ingestion period. Total SCFA concentration increased over time throughout the caecocolonic tract with PoS, but was not modified with the basal diet. While propionate concentration was unchanged, butyrate concentration was highly increased by PoS at each time period in both the caecum and colon. Moreover, the butyrogenic effect of PoS increased over time, and the amount of butyrate was increased 6-fold in the caecum and proximal colon and 3-fold in the distal colon after 6 months compared with 0.5 months. Accordingly, the ratio butyrate :total SCFA increased over time throughout the caecocolonic tract (12.6 (SE 2.8) v. 28 (SE 1.8) \% in the caecum, 10.5 (SE 1.4) v. 26.8 (SE 0.9) \% in the proximal colon, and 7.3 (SE 2.4) v. 23.9 (SE $2.7) \%$ in the distal colon at 0.5 v. 6 months respectively), while the proportion of acetate decreased. Neither the proportion nor the concentration of butyrate was modified over time with the basal diet. Butyrate production was thus promoted by long-term ingestion of PoS, from the caecum towards the distal colon, which suggests that a slow adaptive process occurs within the digestive tract in response to a chronic load of indigestible carbohydrates.
\end{abstract}

Butyrate: Colonic fermentation: Resistant starch

There is increasing evidence that short-chain fatty acids (SCFA), the end-products of colonic fermentation, have specific effects on gut function and metabolism. In this respect, butyrate production, as the preferential colonocyte energy source (Darcy-Vrillon \& Duée, 1995; Roediger, 1995), is of particular interest since it contributes to the maturation of colonic epithelium (Cherbuy et al. 1995) and to mucosal regeneration in the event of atrophy (Sakata, 1987; Tappenden et al. 1997). Butyrate also has antiproliferative effects on tumour cells in vitro, which suggests that it may protect against tumourigenesis. It inhibits DNA synthesis and arrests cultured cancerous cells in the $G_{1}$ phase of the cell cycle (Toscani et al. 1988; Siavoshian et al. 1997). It induces differentiation of these cells, producing a phenotype typically associated with the normal mature cell (Whitehead et al. 1986), and inhibits the expression of several proto-oncogenes relevant to colonic carcinogenesis (Young \& Gibson, 1995). In addition, SCFA influence gastrointestinal motility (Ropert et al. 1996; Cherbut et al. 1998), release several intestinal peptides, stimulate mucosal blood flow (Mortensen et al. 1994), and enhance fluid and $\mathrm{Na}$ absorption (Roediger \& Moore, 1981). As butyrate appears to be the most potent SCFA for all these physiological effects, many nutritionists have tried to vary its concentration in the gastrointestinal tract through the use of diets. However, the mechanisms controlling colonic butyrate production are still largely unknown.

Starches, and certain dietary fibres such as wheat bran, can produce more butyrate than other carbohydrates (McIntyre et al. 1993; Salvador et al. 1993; Martin et al. 1998). However, many factors other than substrate determine the pattern of SCFA production. Of course, the relative proportion and/or activity of bacterial genera is a key factor (Macfarlane \& Gibson, 1995) as well as environmental conditions such as fluid rate and $\mathrm{pH}$. Moreover, the time required for intestinal microbiota to adapt to the chronic load of a substrate may be important. For instance, caecal butyrate concentration increased over time in rats fed with gum arabic (Tulung et al. 1987) or cooked haricot beans (Key \& Mathers, 1995). Bianchini et al. (1992) found lower acetate : butyrate ratios in rat caecal contents after $105 \mathrm{~d}$ of a maize-starch diet than after $30 \mathrm{~d}$. In vitro fermentation of 
guar gum with faeces from rats adapted to a guar-containing diet showed that butyrate production increased with the length of the adaptation period (Weaver et al. 1996). These findings suggest that prolonged feeding of a substrate with potential for butyrate production may select butyrate-producing bacteria and enhance the concentration and molar proportion of butyrate in the hindgut.

In the present study, we tested the hypothesis that longterm and short-term ingestion of resistant potato starch, which is known to be a potent butyrogenic substrate (Martin et al. 1998), would produce different concentrations and molar proportions of butyrate throughout the caecocolonic tract. Rats, which provide a suitable model for access to the contents of the entire caecocolonic tract, were fed on either a low-fibre diet containing starch or the same diet enriched with resistant starch from potato for $0 \cdot 5,2$ and 6 months.

\section{Materials and methods}

\section{Animals and diets}

Thirty-six male Wistar rats (Janvier, Le Genest Saint Isles, France), with an initial mean weight of 115 (SE 1) g, were divided into six groups of six rats each and fed on two different diets for $0 \cdot 5,2$ or 6 months. Rats were placed in suspended wire-mesh-bottomed cages so that coprophagy was not possible. The two experimental diets differed only in the proportions of pregelatinized maize starch and raw potato starch (Table 1). Raw potato starch was included in the potato starch diet $(\mathrm{PoS})$ at the expense of maize starch at a level of about $120 \mathrm{~g} / \mathrm{kg}$. As raw potato starch contained $765 \mathrm{~g}$ resistant starch $/ \mathrm{kg}$, the amount of resistant starch provided by $\mathrm{PoS}$ was $90 \mathrm{~g} / \mathrm{kg}$. Resistant starch was determined by the method of Champ et al. (1999). Briefly, resistant starch was defined as that starch of the raw $\operatorname{PoS}$ which was not hydrolysed by incubation with $\alpha$-amylase (EC 3.2.1.1) in vitro. Amyloglucosidase (EC 3.2.1.3) was added to avoid inhibition by by-products of amylase digestion. Hydrolysis products were extracted with ethanol $(800 \mathrm{ml} / \mathrm{l})$ and discarded.

Table 1. Composition $(\mathrm{g} / \mathrm{kg})$ of the basal and resistant potato starch (PoS) diets

\begin{tabular}{lcc}
\hline Diet ... & Basal & PoS \\
\hline Pregelatinized maize starch & 646 & 528.3 \\
Raw potato starch & 0 & 117.7 \\
Soluble casein & 204 & 204 \\
DL-Methionine & 3.7 & 3.7 \\
Maize oil & 18.5 & 18.5 \\
Lard & 58.5 & 58.5 \\
Mineral mixture† & 43.7 & 43.7 \\
Vitamin mixture & 5.6 & $5 \cdot 6$ \\
Cellulose & 20.0 & 20.0 \\
\hline
\end{tabular}

* Raw potato starch contained $765 \mathrm{~g}$ resistant $\mathrm{starch} / \mathrm{kg}$ determined by the method of Champ et al. (1999).

†Provided the following ( $\mathrm{g} / \mathrm{kg}$ diet): $\mathrm{Ca}_{2}\left(\mathrm{PO}_{4}\right)_{3}$ 16.606, $\mathrm{K}_{2}\left(\mathrm{PO}_{4}\right)_{3} 10.488$ $\mathrm{CaCO}_{3}$ 7.973, $\mathrm{NaCl} 3.059, \mathrm{MgSO}_{4} 3.933, \mathrm{FeSO}_{4} 0.306, \mathrm{ZnSO}_{4} 0.218$, $\mathrm{MnSO}_{4}$ 0.197, CuSO $40.044, \mathrm{CoSO}_{4} 4 \times 10^{-4}, \mathrm{~K}_{2} \mathrm{HSO}_{4} 4 \times 10^{-4}, \mathrm{NH}_{3}\left(\mathrm{SO}_{4}\right)_{2}$ $4 \times 10^{-4}, \mathrm{MgO} 0.874$

¥Provided the following (mg/kg diet): choline $(500 \mathrm{~g} / \mathrm{kg}) 4535 \cdot 7, \alpha$-tocopherol $(500 \mu \mathrm{l} / \mathrm{g}) 451.4$, retinyl acetate $(500 \mu \mathrm{l} / \mathrm{g}) 45 \cdot 4$, cholecalciferol $(100 \mu \mathrm{l} / \mathrm{g})$ 22.4 , nicotinic acid 45.4 , calcium pantothenate $D 45.4$, thiamine hydrochloride $5 \cdot 6$, riboflavin 9 , pyridoxine hydrochloride $5 \cdot 6$, ascorbic acid $113 \cdot 1$, pteroylmonoglutamic acid $2 \cdot 24, p$-aminobenzoic acid $113 \cdot 1$, cyanocobalamin $(1 \mathrm{~g} / \mathrm{kg})$ $67 \cdot 8$, rovimix H2 (biotin D $2 \mathrm{~g} / \mathrm{kg}$ ) 22.7, menadione $2 \cdot 2$, meso-inositol 113.1 .
The resistant starch was then solubilized with $2 \mathrm{M}-\mathrm{KOH}$ and hydrolysed with amyloglucosidase. Glucose was analysed using the u.v. method (Boehringer Mannheim, catalogue no. 716 251; Mannheim, Germany). Rats were individually housed in suspended wire-mesh-bottomed cages and maintained at $23^{\circ}$ in an animal room with a $12 \mathrm{~h}$ light-dark cycle. Food and water were allowed ad libitum. Food intake and body weight were recorded every $2-3 \mathrm{~d}$ during the first 2 weeks, and then twice monthly. All experiments were in accordance with National Research Council guidelines for the care and use of laboratory animals (Maurin-Blanchet, 1997).

\section{Transit time and faecal output}

At 1 week before killing, rats were placed individually in metabolic cages and acclimated for $2 \mathrm{~d}$. On the third day, $4 \mathrm{ml}$ PEG 4000 (100 ml/l) was administered by oral administration to each rat. PEG is a soluble marker of transit; however, it is possible to use it to evaluate total transit time. First, it has a very high capacity for dispersion in the aqueous phase and hydrated components of luminal contents, which represents about $75 \%$ of caecal contents and $50 \%$ of stools in the rat. Second, it has been shown that the overall transit times of solids and liquids are not significantly different in non-ruminant animals (Van Soest et al. 1983; Luick \& Penner, 1991; Hammer \& Phillips, 1993). The faeces of rats fed with PEG were then collected and weighed every $3 \mathrm{~h}$ for $4 \mathrm{~d}$. Collected faeces were freeze-dried, weighed and pulverized to determine PEG concentration according to the method of Hyden (1955). Mean transit time was calculated as the time required for the excretion of $50 \%$ of the initial PEG.

\section{Caecum collection}

At the end of each adaptation period, rats were killed by intracardiac injection of sodium pentobarbital. The caecum and colon were immediately removed and carefully dissected free from fat and mesentery, and the colon was divided into two halves (proximal and distal) before the contents were removed and weighed. Caecal content was divided into four parts: (1) about $0.8 \mathrm{~g}$ was collected into a sterile assay tube for bacterial enumeration; (2) about $0.2 \mathrm{~g}$ was immediately frozen at $-80^{\circ}$ for further analysis of lactate; (3) about $0.3 \mathrm{~g}$ was added to $0.75 \mathrm{ml} \mathrm{HgCl}_{2}$ solution $(1 \mathrm{~g} / \mathrm{l})$ and $0.105 \mathrm{ml}$ $\mathrm{H}_{3} \mathrm{PO}_{4}$ solution $(50 \mathrm{ml} / \mathrm{l})$ and frozen at $-80^{\circ}$ for further analysis of SCFA; and (4) residual material was used for DM determination. A portion $(0 \cdot 3 \mathrm{~g})$ of colonic contents was sampled and added to $0.75 \mathrm{ml}$ (proximal colon) or $0.9 \mathrm{ml}$ (distal colon) $\mathrm{HgCl}_{2}$ solution $(1 \mathrm{~g} / \mathrm{l})$ and $0 \cdot 105 \mathrm{ml} \mathrm{H}_{3} \mathrm{PO}_{4}$ solution $(50 \mathrm{ml} / \mathrm{l})$ for SCFA analysis. The weight of each portion was recorded precisely before further treatment.

\section{Bacterial enumeration}

Samples for the enumeration of selected genera of colonic bacteria were serially diluted 10-fold with one-fourth strength peptone-water anaerobic broth within $2 \mathrm{~h}$ after collection. A $100 \mu \mathrm{l}$ sample of the appropriate dilution was inoculated onto each of two duplicate plates using unselective media 
for the enumeration of total anaerobes (Wilkins Chalgren agar) and total aerobes (nutrient agar), and selective media for Enterobacteriaceae (McConkey no. 2), Streptococcus sp. (azide blood agar base), Bacteroides fragilis group (Bacteroides mineral salt medium, Macfarlane et al. 1990), Lactobacillus sp. (Rogosa agar) and total lactic acid bacteria, i.e. Streptococcus sp., Lactobacillus sp. and Bifidobacterium sp. (Man Rogosa Sharp agar). Lactic acid bacteria are known to produce lactic acid as a major endproduct of metabolism. In the large intestine, these bacteria can be considered to include bifidobacteria (Macfarlane \& Gibson, 1997). Plates were incubated aerobically or in an anaerobic chamber $\left(\mathrm{H}_{2}-\mathrm{CO}_{2}-\mathrm{N}_{2}, 5: 10: 85\right.$, by vol.) for 24 or $72 \mathrm{~h}$ as appropriate. After incubation, single colonies were counted, and the results were expressed as the $\log _{10}$ of the colony-forming unit per wet weight of the initial material.

\section{Short-chain fatty acids and lactate analysis}

Caecal contents of rats receiving the same diet during the same period were pooled before lactate analysis. Lactate concentrations were determined enzymically using L- and D-lactate dehydrogenases (EC 1.1.1.27/28; D-Lactic/L-Lactic, Boehringer Mannheim). SCFA were analysed by GC according to Jouany (1982) on supernatant fractions of thawed samples centrifuged at $8000 \mathrm{~g}$ for $10 \mathrm{~min}$. 4-Methyl valeric acid was used as internal standard.

\section{Chemicals}

Raw potato starch was purchased from Roquette Frères S.A. (Lestrem, France), pregelatinized maize starch from Cerestar (Vilvoorde, Belgium), soluble casein from Touzart et Matignon (Vitry/Seine, France), DL-methionine from Rhône-Poulenc (Commentry, France), and cellulose arbocel from Rettenmaier und Sohne (Heilbronn, Germany). Vitamin and mineral mixtures were prepared by the INRA (Jouy-en-Josas, France). Microbiological media were purchased from Oxoid (Unipath, Dardilly, France). All other chemicals were obtained from the Sigma Chemical Co. (St Quentin Fallavier, France).

\section{Statistical analysis}

Statistical analysis was performed using the Statview F-4.11 package (Abacus Concepts Inc., Berkeley, CA, USA). Twoway ANOVA was used to assess the effects of diet, time of exposure to diet, and interactions between diet and time. When a significant effect of diet was found, means were compared by one-way ANOVA at each time period. Statistical significance was accepted at the $P<0.05$ level.

\section{Results}

\section{Food intake and body weight}

There was no difference between the two diets with respect to food intake and the final weight of animals for each period (Table 2).

\section{Transit time, faecal output and caecal content}

Transit time was not changed by PoS whatever the time period. Regardless of the time period, PoS augmented caecal wet content by increasing both DM and water content (Table 2). Faecal output was also higher with PoS for every time period, although the effect decreased over time due to reduced DM and water excretion (Table 2).

\section{Caecal bacterial counts and caecocolonic concentrations of short-chain fatty acids and lactate}

Except for Streptococcus sp. at 0.5 months, none of the bacterial populations enumerated in the present study was significantly affected by PoS (Table 3 ). The caecal concentration of total SCFA was increased by PoS after 0.5 months and throughout the whole ingestion period with PoS, but was not modified with the basal diet (Table 4). PoS also increased the total SCFA concentration in the proximal and distal colon compared with the basal diet, although the increase remained similar over time (Table 5). Propionate concentration was not changed by PoS, regardless of the segment considered. On the other hand, butyrate concentration was significantly increased in all three segments during PoS ingestion. This resulted in an increase in the

Table 2. Food intake, body weight, transit time, caecal content and faecal output in rats fed on either a low-fibre diet containing starch (Basal) or the same diet enriched with resistant starch from potato (PoS) for $0.5,2$ or 6 months

(Mean values for six rats per treatment with pooled standard errors)

\begin{tabular}{|c|c|c|c|c|c|c|c|c|c|c|}
\hline & \multicolumn{2}{|c|}{0.5 months } & \multicolumn{2}{|c|}{2 months } & \multicolumn{2}{|c|}{6 months } & \multirow{2}{*}{$\begin{array}{l}\text { Pooled } \\
\text { SEM }\end{array}$} & \multicolumn{3}{|c|}{$\begin{array}{l}\text { Statistical significance of effect of: } \\
\qquad(P=)\end{array}$} \\
\hline & Basal & Pos & Basal & Pos & Basal & PoS & & Diet & Time & Diet $\times$ Time \\
\hline Food intake $(g / d)$ & $16 \cdot 9$ & $17 \cdot 5$ & $17 \cdot 2$ & $17 \cdot 6$ & $16 \cdot 9$ & $17 \cdot 3$ & 0.9 & 0.302 & 0.868 & 0.994 \\
\hline Body weight (q) & 229.7 & 232.5 & 386.7 & 390.4 & 484.2 & $498 \cdot 3$ & 18.5 & 0.432 & $<0.0001$ & 0.838 \\
\hline Transit time (h) & $27 \cdot 1$ & 29 & $25 \cdot 1$ & 21.4 & 42.4 & 31.6 & 1.7 & 0.147 & 0.0003 & 0.21 \\
\hline Caecal wet content $(\mathrm{g})$ & 1.1 & $3 \cdot 0^{*}$ & $2 \cdot 1$ & $3 \cdot 1^{*}$ & $3 \cdot 7$ & $4.5^{\star}$ & 0.2 & $<0.0001$ & $<0.0001$ & 0.066 \\
\hline Caecal DM (g) & 0.3 & $0.9^{*}$ & 0.5 & $0.8^{*}$ & 0.8 & $1.2^{*}$ & 0.05 & $<0.0001$ & $<0.0001$ & 0.014 \\
\hline Caecal water (g) & 0.8 & $2 \cdot 1^{*}$ & 1.7 & $2 \cdot 3$ & $2 \cdot 8$ & 3.3 & 0.15 & $<0.0001$ & $<0.0001$ & 0.114 \\
\hline Faecal output (g wet wt/d) & 1.8 & $4 \cdot 0^{*}$ & 2.3 & $3.7^{*}$ & 1.8 & $3.0^{*}$ & 0.2 & $<0.0001$ & 0.003 & 0.02 \\
\hline DM output (g/d) & 1.0 & $2 \cdot 1^{*}$ & 1.2 & $2 \cdot 2^{*}$ & 0.9 & $1.6^{*}$ & 0.09 & $<0.0001$ & 0.0009 & 0.219 \\
\hline Water output (g/d) & 0.8 & $1.9^{*}$ & $1 \cdot 1$ & $1.5^{\star}$ & 0.9 & $1.3^{*}$ & 0.07 & $<0.0001$ & 0.026 & 0.001 \\
\hline
\end{tabular}

Mean values were significantly different from those for the Basal group: ${ }^{*} P<0.05$. 
Table 3. Bacterial composition of caecal contents $\left(\log _{10}\right.$ colony-forming units/g caecal wet content) in rats fed on either a low-fibre diet containing starch (Basal) or the same diet enriched with resistant starch from potato (PoS) for 0.5, 2 or 6 months

(Mean values for six rats per treatment, with pooled standard errors)

\begin{tabular}{|c|c|c|c|c|c|c|c|c|c|c|}
\hline & \multicolumn{2}{|c|}{0.5 months } & \multicolumn{2}{|c|}{2 months } & \multicolumn{2}{|c|}{6 months } & \multirow{2}{*}{$\begin{array}{l}\text { Pooled } \\
\text { SEM }\end{array}$} & \multicolumn{3}{|c|}{$\begin{array}{l}\text { Statistical significance of effect of: } \\
\qquad(P=)\end{array}$} \\
\hline & Basal & PoS & Basal & PoS & Basal & PoS & & Diet & Time & Diet $\times$ Time \\
\hline Facultative anaerobes & 8.0 & $8 \cdot 3$ & $9 \cdot 2$ & $9 \cdot 0$ & 8.4 & $7 \cdot 9$ & 0.13 & 0.579 & 0.004 & 0.449 \\
\hline Enterobacteriaceae & $7 \cdot 4$ & $7 \cdot 6$ & $8 \cdot 3$ & $7 \cdot 7$ & $7 \cdot 3$ & $7 \cdot 2$ & 0.15 & 0.591 & $0 \cdot 133$ & 0.575 \\
\hline Total anaerobes & $10 \cdot 1$ & $10 \cdot 1$ & $10 \cdot 5$ & $10 \cdot 1$ & $10 \cdot 2$ & $9 \cdot 8$ & 0.09 & 0.183 & 0.479 & 0.53 \\
\hline Bacteroides fragilis group & $9 \cdot 4$ & $9 \cdot 7$ & $10 \cdot 0$ & $10 \cdot 0$ & $10 \cdot 1$ & $8 \cdot 6$ & 0.15 & 0.146 & 0.174 & 0.035 \\
\hline Total lactic acid bacteria & 8.7 & $9 \cdot 3$ & $9 \cdot 3$ & $9 \cdot 2$ & $9 \cdot 1$ & $9 \cdot 0$ & 0.11 & 0.537 & 0.738 & 0.376 \\
\hline Lactobacillus sp. & $8 \cdot 2$ & 8.7 & $8 \cdot 9$ & $8 \cdot 7$ & 8.5 & $8 \cdot 7$ & 0.11 & 0.38 & 0.21 & 0.263 \\
\hline Gram positive cocci & $8 \cdot 4$ & $9 \cdot 2^{*}$ & $9 \cdot 2$ & $9 \cdot 4$ & $9 \cdot 0$ & $9 \cdot 6$ & 0.11 & 0.023 & 0.081 & 0.527 \\
\hline
\end{tabular}

Mean values were significantly different from those for the Basal group: ${ }^{\star} P<0.05$.

Table 4. Caecal concentrations of short-chain fatty acids (SCFA) and lactate ( $\mu \mathrm{mol} / \mathrm{g}$ wet caecal content), and pH in rats fed on either a low-fibre diet containing starch (Basal) or the same diet enriched with resistant starch from potato (PoS) for 0.5, 2 or 6 months

(Mean values for six rats per treatment, with their pooled standard errors)

\begin{tabular}{|c|c|c|c|c|c|c|c|c|c|c|}
\hline & \multicolumn{2}{|c|}{0.5 months } & \multicolumn{2}{|c|}{2 months } & \multicolumn{2}{|c|}{6 months } & \multirow{2}{*}{$\begin{array}{l}\text { Pooled } \\
\text { SEM† }\end{array}$} & \multicolumn{3}{|c|}{$\begin{array}{l}\text { Statistical significance of effect of: } \\
\qquad(P=)\end{array}$} \\
\hline & Basal & PoS & Basal & PoS & Basal & Pos & & Diet & Time & Diet $\times$ Time \\
\hline Total SCFA & $62 \cdot 0$ & $90 \cdot 3^{*}$ & 79.4 & $115 \cdot 9^{*}$ & 73.2 & $162 \cdot 3^{*}$ & $6 \cdot 6$ & $<0.0001$ & $<0.0001$ & $<0.0001$ \\
\hline Acetate & 44.0 & $64.9^{*}$ & 55.9 & 66.8 & 47.6 & $94^{*}$ & 3.5 & $<0.0001$ & 0.005 & 0.0007 \\
\hline Propionate & 12.0 & 12.9 & 16.5 & $16 \cdot 4$ & 19.2 & 21.3 & 0.7 & 0.4 & $<0.0001$ & 0.691 \\
\hline Butyrate & 4.9 & $11.2^{*}$ & $5 \cdot 3$ & $31.4^{*}$ & 4.7 & $45 \cdot 4^{*}$ & 3.0 & $<0.0001$ & $<0.0001$ & $<0.0001$ \\
\hline Valerate & 1.1 & 1.3 & 1.7 & 1.2 & 1.6 & 1.6 & 0.07 & 0.273 & 0.067 & 0.2 \\
\hline Lactate & 3.6 & 17.4 & ND & ND & $5 \cdot 6$ & 14.5 & & & & \\
\hline $\mathrm{pH}$ & 7.5 & 6.4 & ND & ND & 7.5 & $6 \cdot 4$ & & & & \\
\hline
\end{tabular}

ND, not determined.

Mean values were significantly different from those for the Basal group: * $P<0.05$.

$\dagger$ Lactate and $\mathrm{pH}$ are shown without SEM because they were determined in contents pooled by diet and ingestion periods $(n 6)$.

Table 5. Concentrations of short-chain fatty acids (SCFA; $\mu \mathrm{mol} / \mathrm{g}$ wet content) in the proximal and distal colon of rats fed on either a low-fibre diet containing starch (Basal) or the same diet enriched with resistant starch from potato (PoS) for $0.5,2$ or 6 months

(Mean values for six rats per treatment, with their pooled standard errors)

\begin{tabular}{|c|c|c|c|c|c|c|c|c|c|c|}
\hline & \multicolumn{2}{|c|}{0.5 months } & \multicolumn{2}{|c|}{2 months } & \multicolumn{2}{|c|}{6 months } & \multirow{2}{*}{$\begin{array}{l}\text { Pooled } \\
\text { SEM }\end{array}$} & \multicolumn{3}{|c|}{$\begin{array}{l}\text { Statistical significance of effect of: } \\
\qquad(P=)\end{array}$} \\
\hline & Basal & PoS & Basal & PoS & Basal & PoS & & Diet & Time & Diet $\times$ Time \\
\hline \multicolumn{11}{|l|}{ Proximal colon } \\
\hline Total SCFA & 63.1 & $97 \cdot 7^{*}$ & $58 \cdot 1$ & $103 \cdot 7^{\star}$ & $45 \cdot 3$ & $114.5^{*}$ & 5.9 & $<0.0001$ & 0.995 & 0.166 \\
\hline Acetate & $46 \cdot 7$ & $76 \cdot 7^{*}$ & 39.5 & $65 \cdot 1^{*}$ & 29.6 & $66 \cdot 3^{*}$ & 4 & $<0.0001$ & 0.12 & 0.72 \\
\hline Propionate & 11 & $10 \cdot 1$ & 14.4 & 16 & 11.9 & $16 \cdot 6$ & 0.6 & 0.066 & 0.0009 & 0.067 \\
\hline Butyrate & 4.4 & $10 \cdot 1^{*}$ & $3 \cdot 1$ & $21 \cdot 7^{*}$ & 2.8 & $30 \cdot 5^{\star}$ & $2 \cdot 2$ & $<0.0001$ & 0.017 & 0.005 \\
\hline Valerate & 1 & 0.7 & 1 & 0.9 & 1 & $1 \cdot 1$ & 0.06 & 0.439 & 0.34 & 0.519 \\
\hline \multicolumn{11}{|l|}{ Distal colon } \\
\hline Total SCFA & 33.9 & $84.5^{\star}$ & $44 \cdot 1$ & $78 \cdot 2^{*}$ & 24.5 & $89.5^{*}$ & 5 & $<0.0001$ & 0.781 & 0.048 \\
\hline Acetate & 23.5 & $69 \cdot 7^{*}$ & 33 & $48 \cdot 8^{*}$ & $15 \cdot 5$ & $52 \cdot 7^{*}$ & 3.5 & $<0.0001$ & 0.061 & 0.001 \\
\hline Propionate & $5 \cdot 3$ & $8 \cdot 1$ & $7 \cdot 7$ & $9 \cdot 4$ & $6 \cdot 8$ & $10 \cdot 9$ & 0.5 & 0.003 & 0.118 & 0.54 \\
\hline Butyrate & 4.5 & 6.5 & $2 \cdot 8$ & $19 \cdot 5^{*}$ & $1 \cdot 7$ & $25 \cdot 2^{*}$ & 1.6 & $<0.0001$ & 0.065 & 0.006 \\
\hline Valerate & 0.7 & 0.3 & 0.6 & 0.5 & 0.5 & 0.7 & 0.06 & 0.657 & 0.775 & 0.112 \\
\hline
\end{tabular}

Mean values were significantly different from those for the Basal group: ${ }^{\star} P<0.05$.

ratio butyrate : total SCFA throughout the caecocolonic tract (Fig. 1), while the proportion of acetate decreased. With the basal diet, the molar percentage of propionate increased gradually over time throughout the large bowel (Fig. 1). The PoS-induced increase in butyrate occurred after 2 weeks in the caecum and proximal colon, but only after 2 months in the distal colon. This butyrogenic effect increased gradually and was maximal at 6 months in the three segments. At this time, PoS increased by more than 10-fold the amount of butyrate in the caecum and proximal and distal colon compared with the basal diet (respectively: 206 (SE 20.7) $v$. $17 \cdot 7$ (SE 3.1), 34.3 (SE 14.4) v. 2.1 (SE 0.4), 26 (SE 4.2) v. $2 \cdot 2$ 
Basal

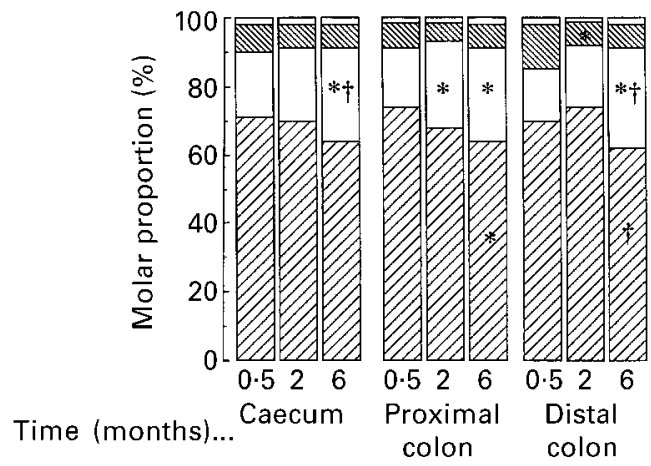

PoS

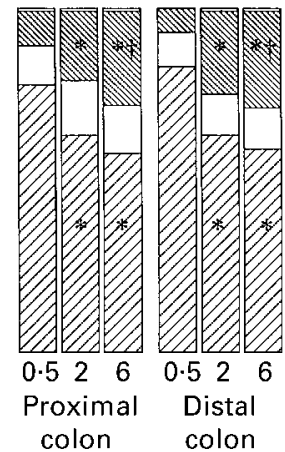

Fig. 1. Molar proportions of individual short-chain fatty acids in the caecocolonic tract of rats fed on either a lowfibre diet containing starch (Basal) or the same diet enriched with resistant starch from potato (PoS) for 0.5, 2 and 6 months. (四), Acetate; (回), propionate; $(\mathbb{\mathbb { Q }})$, butyrate; $(\square)$, valerate. Values are means for six rats per treatment. Mean values were significantly different from those for 0.5 months: ${ }^{*} P<0.05$. Mean values were significantly different from those for 2 months: $\dagger P<0.05$.

(SE 0.6) $\mu \mathrm{mol}$ ). The valerate concentration decreased with PoS in all segments, although the effect was significant only in the distal colon. Caecal lactate concentration was increased with PoS but did not change over time. Concurrently, the $\mathrm{pH}$ of caecal contents was decreased by PoS ingestion.

\section{Discussion}

The purpose of the present study was to investigate largebowel fermentation of a diet enriched in resistant potato starch $(\mathrm{PoS})$ over several months in rats. Our main results show that the caecal concentration of SCFA increased throughout the 6-month experiment with PoS. This was particularly true for butyrate, whose concentration and molar ratio increased over time in the caecum and also in the proximal and distal parts of the colon.

As expected, the addition of resistant starch to the basal diet resulted in an increase in caecal total SCFA concentration and a fall in $\mathrm{pH}$. Furthermore, the SCFA rise was sustained and increased over time. Numerous factors control fermentation and SCFA production in the large bowel. Substrate supply (Macfarlane \& Cummings, 1991), environmental conditions, e.g. $\mathrm{pH}$ and transit time (El Oufir et al. 1996), relative proportions of major bacterial species and the metabolic activity of microbiota (Macfarlane \& Cummings, 1991) may all influence SCFA concentration and pattern. Regarding substrate supply, the daily intakes of raw potato starch were identical at $0 \cdot 5,2$ and 6 months in rats fed on PoS. However, more organic matter may have reached the hindgut in older rats, as suggested by Mathers et al. (1993) since the weight of caecal contents increased over time with both the basal diet and PoS. Nevertheless, the increase in caecal DM was less marked with PoS $(30 \%)$ than with the basal diet $(180 \%)$, while the increase in SCFA was higher with PoS and not significant with the basal diet. Transit time did not seem to account for the increase in SCFA over time since it did not change between 0.5 and 6 months in rats fed on PoS. However, we cannot exclude the possibility that segmental transit time, particularly in the caecum, was modified by PoS over time. Mathers et al. (1997) reported that caecal transit time was prolonged by increasing intake of resistant potato starch in rats. This effect was a function of the hypertrophy of the caecum and of the considerable increase of DM content in that study. In our study, the weight of caecal DM content remained very similar over time in the rats fed on PoS, even if it was increased by PoS compared with the basal diet. A change in caecal transit time over time in the PoS group was therefore unlikely and did not appear as a major factor involved in the increase in SCFA concentration in these conditions. It is also unlikely that the effect was related to the age and body weight of the animals. Although the rapid growth rate of rats is a disadvantage in such a long-term experiment, the use of a control group (basal) and equal feed intakes, as well as the similar body weights for all rats, made it possible to compare measurements over time. No time-induced modifications were noted in the caecocolonic SCFA concentration in rats fed on the basal diet, which is in agreement with a previous study showing that large-bowel fermentation was independent of age in rats fed on an oat-based diet (Mathers et al. 1993).

It is our belief that the time-dependent increase in SCFA with $\mathrm{PoS}$ is indicative of the increased fermentation capacity of the caecum. It is noteworthy that faecal output of wet matter and DM decreased over time with PoS, but did not change significantly with the basal diet. Conjointly with the increase in caecal SCFA concentration, this strongly suggests that PoS utilization by caecal bacteria increased over time, thus decreasing the amount of dry residues excreted in stools. This hypothesis is consistent with the work of other investigators who have shown that the extent of fibre fermentation can increase over time in rats (Tulung et al. 1987). With respect to resistant starch, Brunsgaard et al. (1995) reported that at least 1 month was required to obtain stable starch digestibility in rats fed on a diet containing retrograded high-amylose starch, and that faecal content of glucose was still decreasing after 8 weeks of chronic ingestion of the resistant starch diet. A similar observation was made by Faulks et al. (1989) using resistant pea starch. These authors 
observed a gradual decline in the faecal content of starch and an increase in the apparent digestibility of pea starch throughout the $18 \mathrm{~d}$ of their experiment.

The increase in fermentation capacity may have resulted from the adaptation of intestinal flora, either through the induction of specific amylolytic enzymes or the selection and/ or stimulation of PoS-utilizing bacterial populations. Some saccharolytic enzymes are not spontaneously expressed by bacteria but must be induced (Salyers \& Leedle, 1983). In addition, some workers have suggested that the microflora adapts to the entry of new substrates by changing its composition relative to micro-organisms that are efficient in fermenting them (Tulung et al. 1987; Varel et al. 1987). In our study, it is unlikely that the increase in PoS fermentation was due to specific enzyme induction. Indeed, induction of a specific degradative enzyme is usually a rapid phenomenon (Salyers, 1985). In the particular case of amylases, induction was achieved within a few hours when starch was used as a growth substrate (Cotta, 1988; Macfarlane et al. 1990). Such a delay does not fit with the time required for adaptation in our experimental conditions. In addition, intestinal microbiota spontaneously contains high numbers of amylolytic micro-organisms (Macfarlane \& Englyst, 1986) and elevated amylolytic activity (Englyst $e t$ al. 1987). However, the particular structure of resistant potato starch could impede the activity of these amylolytic bacteria and/or enzymes (Wyatt \& Horn, 1988; Reid et al. 1996). The inherent structure of the polysaccharides might limit the penetration of bacteria into the starch granule (Wyatt \& Horn, 1988), possibly affecting the binding of bacteria to the substrate, which is essential for starch utilization in some bacterial strains (Reeves et al. 1996). This might also alter the activity of the amylolytic enzymes, which are mainly associated with bacterial cells (Englyst et al. 1987). However, extracellular amylolytic activity could also be produced in some bacterial strains (Cotta, 1988). The adaptation we observed could have resulted from a progressive selection of such particular bacterial populations. Yet no major differences were noted in the level of the main caecal bacterial genera with PoS in our investigation, although it cannot be excluded that chronic ingestion of PoS may have selected some bacterial genera which were not investigated by us, such as Eubacterium sp., Clostridium sp., Fusobacterium sp. or Butyrivibrio sp. which have been identified as starch fermenters (Macfarlane \& Englyst, 1986; Macfarlane \& Macfarlane, 1993). Moreover, as the techniques used by us did not allow a distinction to be made between bacterial species, changes in the balance between species within a particular genus could have occurred without being detected. In fact, Kleessen et al. (1997) detected an increase in two species of lactobacilli, L. acidophilus and L. plantarum, as well as in Bifidobacterium sp. in the caecum of rats fed on a diet containing $170 \mathrm{~g}$ raw potato starch $/ \mathrm{kg}$ for 5 months, whereas numbers of bacteroides, clostridia, streptococci and enterobacteria were not changed.

Long-term intake of PoS also increased caecal and colonic concentrations as well as the molar proportion of butyrate. It is well known that fermentation of resistant starch produces high concentrations of butyrate (Scheppach et al. 1988; Phillips et al. 1995; Silvester et al. 1995). However, in our present study, the molar proportion of butyrate increased over time in rats fed on PoS. Previous investigators have already reported such a time-related change in the distribution of end-products of fermentation. In vitro fermentation of guar gum with faeces of rats adapted to a guar-gumcontaining diet produced significantly higher concentrations of butyrate from 11 weeks after the start of the diet (Weaver et al. 1996). The authors concluded that colonic microflora adapts to produce more butyrate if given time and the proper substrate. Previously, Bianchini et al. (1992) reported that the acetate: butyrate ratio was significantly lower in rats fed on a maize-starch diet for $105 \mathrm{~d}$ than in those fed on a sucrose diet for the same period, whereas the ratio values were similar in rats fed on these diets for only $30 \mathrm{~d}$. In addition, it was recently shown that the molar proportion of butyrate declined when resistant potato starch intake increased in rats (Mathers et al. 1997). This result may be further evidence that colonic microbiota needs to adapt to utilize resistant starch. Quite interestingly, the increase in the proportion of butyrate developed up to the distal colon in rats fed on PoS in our present study. It was not apparent at 0.5 months but only after 2 months, and increased even further at 6 months. Similarly, the proportion of butyrate continued to increase in the proximal colon after 2 months, reaching its maximal value at 6 months, whereas it appeared to be stable at 2 months in the caecum. Contrary to results for the caecum, the time-related increase in butyrate concentration was not paralleled by a significant rise in total SCFA concentration in the proximal and distal colon, which suggests that the effect was not due to a displacement of the site or an enhancement of PoS fermentation in the distal parts of the colon but to an orientation of bacterial metabolic activity toward butyrate production. This would be consistent with the hypothesis of a selection over time for specific amylolytic bacteria such as Clostridium sp., Eubacterium sp., Fusobacterium sp. or Butyrivibrio sp., some members of which are butyrate producers (Salyers, 1995).

The increase in butyrate concentration over time throughout the caecocolonic tract may have influenced gut functions. Butyrate, which is the preferred fuel for colonocytes (Roediger, 1995), can stimulate epithelial growth in rats fed on an elemental diet (Sakata, 1987), increase water and $\mathrm{Na}$ absorption in goat colon and isolated human colon (Argenzio et al. 1975; Roediger \& Moore, 1981), and modulate gastrointestinal motility in animals and human subjects (Cherbut, 1995). In the present study, mucosal changes and water absorption were not investigated. However, it is noteworthy that the difference in caecal water content between the basal and PoS groups decreased over time. Similarly, the difference in faecal water output between the two groups was reduced after 2 months. Butyrate may also have contributed to the shorter transit time observed in rats fed on PoS after 6 months, compared with the basal diet, since an increase in butyrate concentration can decrease colonic transit time in rats (Cherbut et al. 1998).

In conclusion, the present study shows that the long-term ingestion of PoS increases caecal SCFA concentration and decreases $\mathrm{pH}$, promotes butyrate production throughout the caecocolonic tract, and increases faecal output. All of these digestive effects are usually considered to be beneficial for host health. In addition, this study sheds light on the slow adaptive process occurring in the digestive tract in 
response to a chronic load of indigestible carbohydrates and suggests that the long-term effects of such products should be evaluated.

\section{Acknowledgements}

The authors are grateful to C. Bonnet, F. Doulay, S. Guéneau and F. Koslowsky for technical assistance with experiments. The study was supported by the French Ministry of Higher Education and Research (grant 94.G.0083).

\section{References}

Argenzio RA, Miller N \& von Englehardt W (1975) Effect of volatile fatty acids on water and ion absorption from the goat colon. American Journal of Physiology 229, 997-1002.

Bianchini F, Caderni G, Magno C, Testeloni G \& Dolara P (1992) Profile of short-chain fatty acids and rectal proliferation in rats fed sucrose or cornstarch diets. Journal of Nutrition 122, 254 261.

Brunsgaard G, Bach Knudsen KE \& Eggum BO (1995) The influence of the period of adaptation on the digestibility of diets containing different types of indigestible polysaccharides in rats. British Journal of Nutrition 74, 833-848.

Champ M, Noah L, Loizeau G \& Kozlowski F (1999) Analytical methods for resistant starch. In Complex Carbohydrate in Foods: Definition, Functionality, and Analysis [S Cho, L Prosky and M Dreher, editors]. New York, NY: Marcel Dekker Co.

Cherbut C (1995) Effects of short chain fatty acids on gastrointestinal motility. In Physiological and Clinical Aspects of Short Chain Fatty Acids, pp. 191-207 [JH Cummings, JL Rombeau and T Sakata, editors]. Cambridge: Cambridge University Press.

Cherbut C, Ferrier L, Rozé C, Anini Y, Blottière H, Lecannu G \& Galmiche JP (1998) Short-chain fatty acids modify colonic motility through nerves and polypeptide YY release in the rat. American Journal of Physiology 275, G1415-G1422.

Cherbuy C, Darcy-Vrillon B, Morel MT, Pegorier JP \& Duée PH (1995) Effect of germfree state on the capacities of isolated rat colonocytes to metabolize n-butyrate, glucose, and glutamine. Gastroenterology 109, 1890-1899.

Cotta MA (1988) Amylolytic activity of selected species of ruminal bacteria. Applied Environmental Microbiology 54, 772-776.

Darcy-Vrillon B \& Duée PH (1995) Fibre effect on nutrient metabolism in splanchnic and peripheral tissues. In Dietary Fibre: Mechanisms of Action in Human Physiology and Metabolism, pp. 83-94 [C Cherbut, JL Barry, D Lairon and M Durand, editors]. Paris: John Libbey Eurotext.

El Oufir L, Flourié B, Bruley des Varannes S, Barry JL, Cloarec D, Bornet F \& Galmiche JP (1996) Relations between transit time, fermentation products, and hydrogen-consuming flora in healthy humans. Gut 38, 870-877.

Englyst HN, Hay S \& Macfarlane GT (1987) Polysaccharide breakdown by mixed populations of human faecal bacteria. FEMS Microbiology and Ecology 95, 163-171.

Faulks RM, Southon S \& Livesey G (1989) Utilization of alphaamylase (EC 3.2.1.1)-resistant maize and pea (Pisum sativum) starch in the rat. British Journal of Nutrition 61, 291-300.

Hammer J \& Phillips SF (1993) Fluid loading of the human colon: effects on segmental transit and stool composition. Gastroenterology 105, 988-998.

Hyden S (1955) A turbidimetric method for the determination of higher polyethylene glycols in biological materials. Annals of the Royal Agricultural College of Sweden 22, 139-145.

Jouany JP (1982) Dosage des acides gras volatils (AGV) et des alcools dans les contenus digestifs, les jus d'ensilage, les cultures bactériennes et les contenus des fermenteurs anaérobies (Determination of volatile fatty acids and alcohols in digestive contents, ensilage juices, bacterial cultures and anaerobic fermenter contents). Science des Aliments 2, 131-144.

Key FB \& Mathers JC (1995) Digestive adaptations of rats given white bread and cooked haricot beans (Phasoleus vulgaris): large bowel fermentation and digestion of complex carbohydrates. British Journal of Nutrition 74, 393-406.

Kleessen B, Stoof G, Proll J, Schmiedl D, Noack J \& Blaut M (1997) Feeding resistant starch affects fecal and cecal microflora and short-chain fatty acids in rats. Journal of Animal Science $\mathbf{7 5}$, 2453-2462.

Luick B \& Penner MH (1991) Nominal response of passage rates to fiber particle size in rats. Journal of Nutrition 121, 19401947.

Macfarlane GT \& Cummings JH (1991) The colonic flora, fermentation, and large bowel digestive function. In The Large Intestine: Physiology, Pathophysiology and Disease, pp. 51-92 [SF Phillips, JH Pemberton and RG Shorter, editors]. New York, NY: Raven Press.

Macfarlane GT \& Englyst HN (1986) Starch utilization by the human large intestinal microflora. Journal of Applied Bacteriology 60, 195-201.

Macfarlane GT \& Gibson GR (1995) Microbiological aspects of the production of short-chain fatty acids in the large bowel. In Physiological and Clinical Aspects of Short-chain Fatty Acids, pp. 87-105 [JH Cummings, JL Rombeau and T Sakata, editors]. Cambridge: Cambridge University Press.

Macfarlane GT \& Gibson GR (1997) Carbohydrate fermentation, energy transduction and gas metabolism in the human large intestine. In Gastrointestinal Microbiology: Gastrointestinal Ecosystems and Fermentations, vol. 1, pp. 269-318 [RI Mackie and BA White, editors]. New York, NY: Chapman \& Hall.

Macfarlane GT, Hay S, Macfarlane S \& Gibson GR (1990) Effect of different carbohydrates on growth, polysaccharidase and glycosidase production by Bacteroides ovatus, in batch and continuous culture. Journal of Applied Bacteriology 68, 179-187.

Macfarlane GT \& Macfarlane S (1993) Factors affecting fermentation reactions in the large bowel. Proceedings of the Nutrition Society 52, 367-373.

McIntyre A, Gibson PR \& Young GP (1993) Butyrate production from dietary fibre and protection against large bowel cancer in a rat model. Gut 34, 386-391.

Martin LJM, Dumon HJW \& Champ MMJ (1998) Production of short-chain fatty acids from resistant starch in a pig model. Journal of the Science of Food and Agriculture 77, 71-80.

Mathers JC, Kennard J \& James OFW (1993) Gastrointestinal responses to oat consumption in young adult and elderly rats: digestion, large bowel fermentation and crypt cell proliferation rates. British Journal of Nutrition 70, 567-584.

Mathers JC, Smith H \& Carter S (1997) Dose-response effects of raw potato starch on small-intestinal escape, large-bowel fermentation and gut transit time in the rat. British Journal of Nutrition 78, 1015-1029.

Maurin-Blanchet H (1997) Le “G.I.R.C.O.R.”, Groupe Interprofessionnel de Réflexion et de Communication sur la Recherche. Bulletin de l'Academie Véterinaire de France 70, 295-306.

Mortensen FV, Nielsen H, Aalkjaer C, Mulvany MJ \& Hessov I (1994) Short chain fatty acids relax isolated resistant arteries from the human ileum by a mechanism dependent on anion exchange. Pharmacology Toxicology 75, 181-185.

Phillips J, Muir JG, Birkett A, Lu ZX, Jones GP, O’Dea K \& Young GP (1995) Effect of resistant starch on fecal bulk and fermentation-dependent events in humans. American Journal of Clinical Nutrition 62, 121-130.

Reeves AR, D'Ellia JN, Frias J \& Salyers AA (1996) A Bacteroides thetaiotaomicron outer membrane protein that is essential for 
utilization of maltooligosaccharides and starch. Journal of Bacteriology 178, 823-830.

Reid CA, Hillman K, Henderson C \& Glass H (1996) Fermentation of native and processed starches by the porcine caecal anaerobe Clostridium butyricum (NCIMB 7423). Journal of Applied Bacteriology 80, 191-198.

Roediger WEW (1995) The place of short-chain fatty acids in colonocyte metabolism in health and ulcerative colitis: the impaired colonocyte barrier. In Physiological and Clinical Aspects of Short-chain Fatty Acids, pp. 337-351 [JH Cummings, JL Rombeau and T Sakata, editors]. Cambridge: Cambridge University Press.

Roediger WEW \& Moore A (1981) The effect of short-chain fatty acids on sodium absorption in the isolated human colon perfused through the vascular bed. Digestive Disease and Science 26, 100-106.

Ropert A, Cherbut C, Roze C, Le Qullec A, Holst JJ, Fu-Cheng X, Bruley des Varannes S \& Galmiche JP (1996) Colonic fermentation and proximal gastric tone in humans. Gastroenterology 111, 289-296.

Sakata T (1987) Stimulatory effect of short-chain fatty acids on epithelial cell proliferation in the rat intestine: a possible explanation for trophic effects of fermentable fibre, gut microbes and luminal trophic factors. British Journal of Nutrition 58, 95-103.

Salvador V, Cherbut C, Barry JL, Bertrand D, Bonnet C \& DelortLaval J (1993) Sugar composition of dietary fibre and shortchain fatty acid production during in vitro fermentation by human bacteria. British Journal of Nutrition 70, 189-197.

Salyers AA (1985) Breakdown of polysaccharides by human intestinal bacteria. Journal of Environmental Pathology, Toxicology and Oncology 5, 211-231.

Salyers AA (1995) Fermentation of polysaccharides by human colonic anaerobes. In Dietary Fibre: Mechanisms of Action in Human Physiology and Metabolism, pp. 29-35 [C Cherbut, JL Barry, D Lairon and M Durand, editors]. Paris: John Libbey Eurotext.

Salyers AA \& Leedle JAZ (1983) Carbohydrate metabolism in the human colon. In The Human Intestinal Flora in Health and Disease, pp. 129-146 [D Hendges, editor]. New York, NY: Academic Press.

Scheppach W, Fabian C, Sachs M \& Kasper H (1988) The effect of starch malabsorption on fecal short-chain fatty acid excretion in man. Scandinavian Journal of Gastroenterology 26, 755-759.

Siavoshian S, Blottière HM, Cherbut C \& Galmiche JP (1997) Butyrate stimulates cyclin D and p21 and inhibits cyclin-dependent kinase 2 expression in HT-29 colonic epithelial cells. Biochemical and Biophysical Research Communications 232, 169-172.

Silvester KR, Englyst HN \& Cummings JH (1995) Ileal recovery of starch from whole diets containing resistant starch measured in vitro and fermentation of ileal effluent. American Journal of Clinical Nutrition 62, 403-411.

Tappenden KA, Thomson ABR, Wild GE \& McBurney MI (1997) Short-chain fatty acid-supplemented total parenteral nutrition enhances functional adaptation to intestinal resection in rats. Gastroenterology 112, 792-802.

Toscani A, Soprano DR \& Soprano KJ (1988) Molecular analysis of sodium butyrate-induced growth arrest. Oncogenes Research 3, 223-238.

Tulung B, Rémésy C \& Demigné C (1987) Specific effects of guar gum or gum arabic on adaptation of cecal digestion to high fiber diets in the rat. Journal of Nutrition 117, 1556-1561.

Van Soest PJ, Uden P \& Wrick KF (1983) Critique and evaluation of markers for use in nutrition of humans and farm and laboratory animals. Nutrition Reports International 27, 17-28.

Varel VH, Robinson IM \& Jung HJG (1987) Influence of dietary fiber on xylanolytic and cellulolytic bacteria of adult pigs. Applied Environmental Microbiology 53, 22-26.

Weaver GA, Tangel CT, Krause JA, Alpern HD, Jenkins PL, Parfitt MM \& Stragand JJ (1996) Dietary guar gum alters colonic microbiotal fermentation in azoxymethane-treated rats. Journal of Nutrition 126, 1979-1991.

Whitehead RH, Young GP \& Bhathal PS (1986) Effects of short chain fatty acids on a new human colon carcinoma cell line (LIM1215). Gut 27, 1457-1463.

Wyatt GM \& Horn N (1988) Fermentation of resistant food starches by human and rat intestinal bacteria. Journal of the Science of Food and Agriculture 44, 281-288.

Young GP \& Gibson PR (1995) Butyrate and the human cancer cell. In Physiological and Clinical Aspects of Short Chain Fatty Acids, pp. 319-335 [JH Cummings, JL Rombeau and T Sakata, editors]. Cambridge: Cambridge University Press. 